NBER WORKING PAPER SERIES

HOW DO FIRMS BUILD MARKET SHARE?

Doireann Fitzgerald

Anthony Priolo

Working Paper 24794

http://www.nber.org/papers/w24794

\author{
NATIONAL BUREAU OF ECONOMIC RESEARCH \\ 1050 Massachusetts Avenue \\ Cambridge, MA 02138 \\ July 2018
}

The views expressed herein are those of the authors and not necessarily those of the Federal Reserve Bank of Minneapolis, the Federal Reserve System, or the National Bureau of Economic Research. All results are calculated (or derived) based on data from The Nielsen Company (US), LLC and marketing databases provided by the Kilts Center for Marketing Data Center at The University of Chicago Booth School of Business. The conclusions drawn from the Nielsen data are those of the researchers and do not reflect the views of Nielsen. Nielsen is not responsible for, had no role in, and was not involved in analyzing and preparing the results reported herein.

NBER working papers are circulated for discussion and comment purposes. They have not been peer-reviewed or been subject to the review by the NBER Board of Directors that accompanies official NBER publications.

(C) 2018 by Doireann Fitzgerald and Anthony Priolo. All rights reserved. Short sections of text, not to exceed two paragraphs, may be quoted without explicit permission provided that full credit, including $(\mathrm{C}$ notice, is given to the source. 
How Do Firms Build Market Share?

Doireann Fitzgerald and Anthony Priolo

NBER Working Paper No. 24794

July 2018

JEL No. E3,L11,M3

\begin{abstract}
$\underline{\text { ABSTRACT }}$
The question of how firms build market share matters for firm dynamics, business cycles, international trade, and industrial organization. Using Nielsen Retail Scanner data for the United States, we document that in the consumer food industry, brands experience substantial growth in market share in the first four years after successful entry into a regional market. However, markups are flat with respect to brand tenure. This finding is at odds with a large literature on customer markets which argues that firms acquire customers by temporarily offering low markups, and later raise markups once customers are locked in. However, it is consistent with a literature which emphasizes the importance of marketing and advertising activities for building market share.
\end{abstract}

Doireann Fitzgerald

Federal Reserve Bank of Minneapolis

90 Hennepin Ave

Minneapolis, MN 55401

and NBER

doireann.fitzgerald@gmail.com

Anthony Priolo

Department of Economics

University of Minnesota

prio1011@umn.edu 


\title{
How Do Firms Build Market Share?*
}

\author{
Doireann Fitzgerald ${ }^{\dagger}$ and Anthony Priolo
}

June $28,2018^{\S}$

\begin{abstract}
The question of how firms build market share matters for firm dynamics, business cycles, international trade, and industrial organization. Using Nielsen Retail Scanner data for the United States, we document that in the consumer food industry, brands experience substantial growth in market share in the first four years after successful entry into a regional market. However, markups are flat with respect to brand tenure. This finding is at odds with a large literature on customer markets which argues that firms acquire customers by temporarily offering low markups, and later raise markups once customers are locked in. However, it is consistent with a literature which emphasizes the importance of marketing and advertising activities for building market share.
\end{abstract}

\section{Introduction}

A large literature on "customer markets" posits that firms initially offer low markups to attract new customers, but later exploit customer lock-in due to e.g. search frictions to increase the markups they charge. ${ }^{1}$ Some macroeconomists have argued that this behavior

${ }^{*}$ The views expressed herein are those of the authors and not necessarily those of the Federal Reserve Bank of Minneapolis or the Federal Reserve System. All results are calculated (or derived) based on data from The Nielsen Company (US), LLC and marketing databases provided by the Kilts Center for Marketing Data Center at The University of Chicago Booth School of Business. The conclusions drawn from the Nielsen data are those of the researchers and do not reflect the views of Nielsen. Nielsen is not responsible for, had no role in, and was not involved in analyzing and preparing the results reported herein.

${ }^{\dagger}$ Federal Reserve Bank of Minneapolis and NBER, doireann.fitzgerald@gmail.com

${ }_{\ddagger}^{\ddagger}$ Department of Economics, University of Minnesota, priol011@umn.edu

$\S$ First Draft: May 2018

${ }^{1}$ See, e.g. Phelps and Winter (1970), Bils (1989), Klemperer (1995), and more recently, Ravn et. al (2006), Nakamura and Steinsson (2011), Gourio and Rudanko (2014), Gilchrist et al (2017) and Paciello et al (2017). 
may contribute to countercyclical markups and hence to a countercyclical labor wedge. However, an alternative literature in marketing and international trade posits that firms instead use non-price actions such as marketing and advertising to build market share. ${ }^{2}$ In the context of this literature, the procyclical behavior of advertising is a challenge to markup-based explanations of the labor wedge. ${ }^{3}$

We use Nielsen Retail Scanner data on consumer food products to test the customer markets hypothesis by tracking how quantities and prices evolve following market entry, controlling for marginal cost. Our test is based on the assumption that while entrants have only new customers, the share of new customers in total sales decreases with tenure in a market. We find that controlling for marginal cost, brands which successfully enter a product segment in a particular regional market build market share significantly in the four years following entry. However, markups do not rise over this time horizon. If anything, there is a slight decline in markups with tenure, that is statistically, if not economically, significant. This behavior of markups rejects the customer markets model of market share acquisition in the consumer food industry.

In addition to our baseline findings on the behavior of market share and markups, we find that the extensive margin of stores plays an important role in sales growth within a market. In the light of the fact that placing a product in stores is costly for firms, this is suggestive evidence that marketing expenditures (rather than markups) play an important role in building market share.

The Nielsen Retail Scanner data set has several attractive features for our purposes. Unlike consumer products such as household goods and apparel, the market for consumer food is likely to be geographically segmented, allowing us to treat different regions as different distinct markets. Meanwhile Nielsen-covered stores account for over $50 \%$ of grocery and drug store spending in the United States. So while market entry is censored by the fact that coverage is not $100 \%$, nevertheless the degree of censoring is much less than in alternative data sets such as the Nielsen Consumer Panel and the IRI data.

Our empirical strategy relies on the fact that brands are not always introduced simultaneously across all markets in the U.S. Instead, entry is staggered, inducing variation in tenure across regional markets within a brand. This allows us to use a fixed effects strategy to control for supply-side factors such as marginal cost, and hence identify the behavior of markups. We also use a fixed effects strategy to control for demand-side factors that affect all brands selling a given product in a particular regional market equally. This implies that our quantity results map into the behavior of market share.

\footnotetext{
${ }^{2}$ See, e.g. Arkolakis (2010), Eaton et al (2011), Drozd and Nosal (2012), and Eaton et al (2014).

${ }^{3}$ See Hall (2014).
} 
Our findings are consistent with recent work based on customs data, which also finds that quantities grow while markups are flat in successful export spells. ${ }^{4}$ Our findings on the slow growth of market share are consistent with those of Foster, Haltiwanger and Syverson (2008), who use U.S. Census of Manufactures data on a restricted set of industries producing relatively homogeneous goods. In contrast to Foster et al, we focus on within-firm, crossmarket heterogeneity and find no role for prices in explaining differential growth of market share across different markets. Meanwhile, our work is also related to Hottman, Redding and Weinstein (2016), who use Nielsen data to argue that "product appeal" plays a key role in explaining cross-sectional differences in firm size. We show that "product appeal" (i.e. the behavior of market share conditional on cost and markups) has a striking dynamic pattern. Our work is also related to Argente, Lee and Moreira (2018), who use Nielsen data to look at the product cycle at the UPC level.

The paper is organized as follows. In the second section, we describe the data and provide relevant summary statistics. In the third section, we describe our empirical strategy. In the fourth section, we describe our results. The final section concludes.

\section{Data Description}

\section{$2.1 \quad$ Overview}

Our primary data source is the Nielsen Retail Scanner database for the years 2006-2016. This database contains data on the dollar value and volume (along with the relevant quantity unit) of weekly sales at the store level for approximately 2.6 million barcodes (UPCs) in roughly 35,000 grocery stores, drug stores, and mass merchandisers located throughout the United States. According to Nielsen estimates as of 2011, these data cover $53 \%$ of all-commodity volume $(\mathrm{ACV})$ in grocery stores, $52 \%$ of $\mathrm{ACV}$ in drug stores, and $32 \%$ of $\mathrm{ACV}$ in mass merchandisers.

\subsubsection{Markets}

For each participating store, we know the parent chain, the 3-digit zip code, and the Nielsen Designated Market Area (DMA) where it operates. There are 210 Nielsen-defined DMAs, with coverage in nearly every major U.S. metropolitan area. For the purposes of our empirical analysis, we treat each DMA as a geographically distinct market. We assume that customers can only purchase from firms participating in their local DMA, that they have access to all

\footnotetext{
${ }^{4}$ See Fitzgerald, Haller, \& Yedid-Levi (2017).
} 
UPCs sold in their local market, and that observing positive sales in the Nielsen Retail Scanner database is a good measure of participation in a local DMA by a UPC.

\subsubsection{Products and brands}

The hierarchical structure of the data is as follows. There are ten Nielsen-defined departments. We make use of five of these departments in our analysis: Dry Grocery, Dairy, Deli, Packaged Meat, and Fresh Produce. ${ }^{5}$ We focus on food departments because for the sample period, the market for consumer food is more likely to be geographically segmented than the market for non-food consumer goods. Within each department, there are Nielsen-defined product groups, and within each product group, there are Nielsen-defined product modules. For example, in the Dairy department "CHEESE" is a product group, while "CHEESE NATURAL - MOZZARELLA" is a product module within "CHEESE." There are more than 1,000 product modules in the full set of ten departments. Our baseline definition of a product is a Nielsen-defined product module, and from now on, we refer to product modules simply as "products."

Within products, the finest level of disaggregation is the UPC. For each UPC, we observe the unit of quantity, e.g. "oz", "quart," etc., and the number of units in a package. This allows us to compare quantities across UPCs within products. For example, if Dannon brand yogurt is sold in 42 oz. tubs, while Chobani brand yogurt is sold in 4 oz. 6-packs, we can use ounces as the common unit of quantity, with Chobani being coded as 24 units and Dannon as 42 units. Sometimes, there are multiple units of quantity within a product. Generally, this is because for some UPCs the quantity unit is "counts." In our current analysis, we drop all UPCs where the quantity unit is a count. These observations account for $5.1 \%$ of total value in our five departments. ${ }^{6}$ Occasionally, we observe multiple units of quantity because e.g. some UPCs within a product report quantities in weight, while others report quantities in volume. In these cases, we split the UPCs in the product into two groups according to the relevant unit of quantity, and treat each product-unit of quantity pair as a distinct product.

Nielsen also classifies UPCs into brands. Brands may cross products: roughly one quarter of brands have positive sales in multiple products. In addition, firms may have multiple brands. Hottman, Redding and Weinstein (2016) make use of information embedded in the UPCs to aggregate up to the firm level. To date we have not implemented this in our analysis.

\footnotetext{
${ }^{5}$ In future iterations of this work we plan to make use of Frozen Foods, which is the remaining food department. The other four departments are Alcoholic Beverages, Health \& Beauty Care, Non-Food Grocery and General Merchandise.

${ }^{6}$ This problem is even more severe in non-food departments such as Health and Beauty Care.
} 


\subsection{Aggregation}

We use the product-brand pair as our baseline unit of analysis. This strikes a balance: it allows us to aggregate quantities consistently, while ensuring that we do not have to deal with entry and exit of UPCs that may be due to minor product or packaging modifications. In addition, advertising takes place at the brand (rather than UPC) level, and it is likely that individual brands have separate management teams. ${ }^{7}$ Given our focus on how firms building market share, this makes the brand a convenient place to start. Of course, this means that we do not control for quality as cleanly as an analysis based on UPCs. We return to this issue in discussing the implications of our results. At this point, we do not address how firms may build market share by adding new brands.

We aggregate from weekly data to the annual level, to avoid spurious entry and exit for seasonal products. As already noted, we work for now with the 210 Nielsen-defined DMAs as our geographically segmented markets.

Mechanically, we first aggregate store-level weekly sales value and volume for each UPC up to the annual level. Then, we match UPCs with products, quantity units and brands, and match stores with their respective DMAs. For each product, quantity unit, brand, DMA, and year we record total sales value and total sales volume. Taking the ratio of total sales value to total sales volume, we obtain unit values which we refer to as prices. In addition, we record the number of UPCs and number of stores within the brand-product pair.

Nielsen codes all private label brands as control brands and thus, we cannot distinguish between the sales of two different private label brands in a given DMA. We drop all control brands from the data. In doing so, we drop $20.6 \%$ of sales.

\subsection{Summary statistics}

Table 1 reports the number of distinct products, brands, markets, and product-brand-market triplets present in the data in each year. Collapsing on these dimensions yields a data set with 21 million observations which is the basis for our analysis. It is useful to note that while in the full data set, there are 53 brands per product on average, at the level of the individual market, there are only 18 brands per product on average. This tells us that market penetration at the product-brand level is far from complete, in line with the findings of Bronnenberg, Dhar and Dubé (2007). Our empirical strategy builds on this fact.

In addition to imperfect market penetration in the cross-section, our empirical analysis relies on the fact that the pattern of market participation is not static: we observe frequent episodes of brand entry at the product-market level. We say that a brand enters a product-

\footnotetext{
${ }^{7}$ See Bronnenberg, Dhar and Dubé (2011).
} 
market in year $t$ if it has zero sales in that market in year $t-1$, and positive sales in year $t$. We say that a brand exits a product-market in year $t$ if it has positive sales in year $t$, and zero sales in year $t+1$. Entry is censored in 2006, and exit is censored in 2016. Note that brands can (and do) enter a product-market multiple times during the sample. For the moment, we do not distinguish between entry and re-entry. Figures 1,2, and 3 are scatter plots of the average entry and exit rates (across years) at the product, market, and productmarket levels. In addition, we report average entry and exit rates by year in Table 2. Notice there is substantial entry and exit at all levels. Futhermore, the average share of total sales accounted for by entrants in the year of entry is $1.80 \%$, while the average share of total sales accounted for by brand-product-markets where entry is observed in-sample is $12.5 \%$.

Our empirical analysis also relies on entry at the brand-product level that is non-synchronous across markets. In Table 3 we report the distribution of product-brand-year triplets by the change in the number of markets they participate in relative to the previous year. On average $44 \%$ of product-brand pairs either exit or enter into a new market in any given year. Note that this is a lower bound on churn since product-brands may enter and exit the same number of markets in a given year. This churn is critical to our analysis in that it induces the within-product-brand variation in market tenure and spell duration that we utilize in our empirical strategy.

\section{$3 \quad$ Empirical strategy}

The goal of our empirical strategy is to distinguish between competing models of how firms build market share and, in particular, to examine the role played by markups. We do so by tracking how quantities and prices evolve following market entry. We assume that while entrants have only new customers, the share of new customers in total sales decreases with tenure in a market, and hence the behavior of market shares and markups following entry can shed light on the role of markups in building market share.

Before describing our approach, it is useful to define two variables: market tenure, and completed spell duration. Market tenure is the cumulative number of periods of continuous market participation at the product-brand-market level. Completed spell duration is the maximum market tenure achieved in a product-brand-market-level sales spell, i.e. the market tenure on exit for that spell. Table 4 illustrates these definitions for a hypothetical productbrand pair in a series of markets. In this table, as in our implementation, tenure and duration are top-coded at 5 years. This allows us to assign a duration to (some) sales spells where entry is observed, but exit is censored by the end of the sample.

With those definitions out of the way, there are three elements to our empirical strategy. 
First, we purge the data of variation that is common to all markets served by a product-brand pair, and variation that is common to all brands selling in a particular product-market. In doing so, we remove the first-order effect of cost and quality heterogeneity: better brands may sell more and at lower (or higher) prices in all markets. We also remove the first-order effect of differences in market size and tastes: all brands sell more in bigger and richer markets, and all brands selling a particular product sell more (and potentially at higher prices) in markets with a strong taste for that particular product. This allows us to identify the behavior of market shares and markups,

Second, we focus on product-brand pairs which enter at least one market during our sample period and we examine how quantities, prices, number of stores and number of UPCs evolve with tenure in a market. This allows us to build an understanding of how quickly entrants reach their steady state market share, and what role (if any) is played by prices in this process.

Third, we allow the evolution of quantities, prices, etc. with tenure to differ across sales spells with different completed duration. There are two reasons to do this. Both rely on the assumption that the completed duration of a sales spell depends on the permanent components of product-brand-specific costs, product-market size, and product-brand-marketspecific idiosyncratic demand. If this is the case, controlling for completed spell duration allows us to deal with potential bias in the relationship between quantity, price, etc. and tenure due to correlation between tenure and unobserved idiosyncratic demand. In addition, the efforts firms exert to build market share may to depend on the permanent components of costs, market size, and idiosyncratic demand. By allowing the relationship between quantities, prices, etc. and tenure to differ across firm-product-market observations based on completed duration, we can test whether this is the case.

More precisely, we simultaneously implement these three elements as follows. Let $i$ index brands, let $j$ index products (product modules), let $k$ index markets (DMAs), and let $t$ index time (years). Let $w_{t}^{i j k}$ be log quantity, log price, log number of stores or log number of UPCs. We estimate:

$$
w_{t}^{i j k}=\delta_{t}^{j k}+c_{t}^{i j}+\beta^{\prime}\left(a_{t}^{i j k} \otimes s_{t}^{i j k}\right)+\operatorname{cens}^{i j k}+\varepsilon_{t}^{i j k}
$$

Here, $\delta_{t}^{j k}$ is a product-market-year fixed effect that controls for demand side factors common to all firms in a product-market-year. $c_{t}^{i j}$ is a firm-product-year fixed effect that controls for marginal cost and quality. $a_{t}^{i j k}$ is a vector of indicator variables for firm $i$ 's (topcoded) tenure in market $k$ with product $j$, and $s_{t}^{i j k}$ is a vector of indicators for the (topcoded) duration of 
the relevant sales spell. cens ${ }^{i j k}$ is a vector of indicator variables, for right- and left-censoring of the relevant sales spell. ${ }^{8}$ Lastly, note that $\otimes$ denotes the Kronecker product. Naturally, we do not observe sales spells with market tenure greater than the completed duration so redundant interactions are dropped.

Notice that linear combinations of the coefficients in $\beta$ allow us to map out the average evolution of log quantities and log prices with tenure, for spells of different duration.

In addition, we document the distribution of sales spells of different lengths by estimating the following nonparametric exit hazard:

$$
\operatorname{Pr}\left[X_{t+1}^{i j k}=0 \mid X_{t}^{i j k}=1\right]=\delta_{t}^{j k}+c_{t}^{i j}+\beta^{\prime} a_{t}^{i j k}+\mathrm{cens}^{i j k}+\varepsilon_{t}^{i j k}
$$

Here, $X_{t}^{i j k}=\{0,1\}$ is an indicator variable for participation. The other variables are as defined above, except that observations from right-censored spells are assigned their market tenure rather than being included through an indicator variable for right-censoring. In this expression, cens $^{i j k}$ indicates observations from left-censored spells (for which tenure is not observed).

\section{Results}

In Table 5 we report the distribution of sample value by sales spell duration and market tenure. Clearly, the bulk of the data is accounted for by observations where either tenure or duration, or both, are censored. Nevertheless, $12.5 \%$ of value is accounted for by observations where entry takes place in-sample. Similarly, in Table 6 we report the distribution of observations by sales spell duration and market tenure. In these terms, observations where entry takes place in-sample accounts for nearly half of the observations of the sample.

Table 7 reports the OLS estimates of equation (1) with log revenue, log quantity, log price as dependent variables. Table 8 reports the OLS estimates of (1) with log count of UPCs, log count of stores, and log revenue per store and per UPC as dependent variables. In all cases, the omitted category is sales spells that last exactly one year. The tables report intercepts for spells of different duration, as well as the evolution of the dependent variable throughout a spell relative to its value on entry. Figures 4, 5, 6 and 7 illustrate the trajectories of quantity, price, number of stores, and number of UPCs. These trajectories are calculated by exponentiating the relevant sums of coefficients from Tables 7 and 8. Confidence intervals for these trajectories are tiny.

There are three points to note about these results. First, conditional on costs, higher

\footnotetext{
${ }^{8}$ Spells that are both left- and right-censored are classified as left-censored.
} 
quantities on entry forecast longer survival, while quantities grow by more a factor of 2.8 between the entry year and year 4 in the longest sales spells. Meanwhile, there are humpshaped dynamics of quantities in sales spells where exit is observed. As already noted, since we control throughout for product-market-year effects, these are the dynamics of market share. Since these dynamics of market share are conditional on product-brand-year effects, to the extent that marginal costs are similar across markets, they cannot be driven by costs. Instead, they must be due to movements along the demand curve through changing markups, or shifts in the demand curve faced by individual product-brand pairs in individual markets.

Second, since we condition on costs, we can infer the behavior of markups from the the price equation. Higher markups on entry forecast survival longer than 1 year, though beyond that they have little predictive power. Note that this is based on within-brand cross-market variation after controlling for product-market effects. As such, this fact cannot be attributed to all firms having higher prices in some markets. As regards dynamics of markups, to the extent that prices vary with tenure, they fall with tenure. This is particularly pronounced in the year prior to exit, when prices are on average $9 \%$ below their level on entry. For the longest sales spells, prices are 1\% lower in subsequent years than they are in the year of entry.

The joint behavior of market share and markups in the longest sales spells is contrary to the customer markets hypothesis, which posits that firms charge low markups to attract customers, and subsequently raise markups once customers are locked in. Upon entry into a market, all customers are new. Presumably the share of new customers falls as a brand ages in a market. But we do not find markups rising with tenure; on the contrary, they appear to fall with tenure. This is a feature of the longest sales spells, where presumably brands are likely to endure, and pricing is chosen to trade off current and future demand. It is also a feature of exiting spells, where rather than taking advantage of the fact that exit is imminent by raising prices to extract the maximum from remaining customers, prices actually fall immediately prior to exit. Moreover, given the modest reduction in markups with tenure in successful sales spells, it is unlikely that falling markups alone can account for growth in market share - this would require remarkably elastic demand. Taken together, the behavior of market share and markups in successful spells suggest that firms build market share by shifting their demand curve rather than moving along their demand curve.

Third, the evolution of number of stores and number of UPCs is qualitatively similar to the evolution of quantities. Quantitatively, the number of stores rises more with tenure in successful spells than does the number of UPCs. This suggests two things. First, at least within the context of a brand, selling to more customers is quantitatively more important for sales growth than selling a greater variety of products to the same customers. Second, since 
placing a brand in stores is known to be costly, it suggests a role for marketing expenditures in acquiring access to more customers, and hence shifting demand to build market share.

Table 9 reports the OLS estimates of equation (2). Figure 8 presents the exit probability by market tenure relative to the exit probability of a one-year spell. The rate of exit peaks in the second year following entry, and falls thereafter. This behavior of the exit probability may be suggestive of a role for learning about idiosyncratic demand in explaining the behavior of market share and markups.

\subsection{Relation to the literature}

Our empirical approach is very similar to that in Fitzgerald, Haller and Yedid-Levi (2017) who use customs data on merchandise exports for Ireland to examine the dynamic evolution of quantities and prices post export entry. Our findings are also very similar to theirs. High initial sales forecast survival in a market, and sales grow substantially over the initial years of long-lasting episodes of market participation. Meanwhile, markups are flat with respect to market tenure. One difference between our findings and theirs is that in the Nielsen data, we observe statistically significant price declines prior to exit, while this is not the case in customs data.

While the time horizon in our analysis is much shorter, our finding that cost does not play a key role in the slow growth of market share is consistent with Foster, Haltiwanger and Syverson (2008), who use U.S. Census of Manufactures data on a restricted set of industries producing relatively homogeneous goods. In contrast to Foster et al, we focus on withinfirm, cross-market heterogeneity and find no role for prices in explaining differential growth of market share across different markets.

Our work is also related to Hottman, Redding and Weinstein (2016), who use Nielsen Consumer Panel data to argue that product appeal plays a key role in explaining crosssectional differences in firm size. We show that "product appeal" (i.e. the behavior of market share conditional on cost and markups) has a striking dynamic pattern, and that this dynamic pattern of building market share is unlikely to occur through the mechanisms emphasized in the customer markets hypothesis.

Our findings are also related to those of Argente, Lee and Moreira (2018). They use Nielsen Retail Scanner data to argue that the product cycle in consumer goods is very short, and they emphasize the importance of adding products for firm growth. In contrast to Argente et al., we focus on the brand rather than the UPC as the unit of analysis, and use the sequential roll-out of brands across markets to identify the dynamics of quantities and markups. 


\section{Discussion and conclusions}

The customer markets literature argues that firms use markups as a tool to build market share. More precisely, this literature argues that firms attract new customers by offering them low markups, but then raise markups once customers are locked in. We show that the market for consumer food products does not exhibit these types of dynamics. While there is substantial growth in market share in the initial years of successful sales spells, these episodes are not accompanied by rising markups as the customer markets theory predicts. Instead, if anything, markups fall marginally as market share grows. These patterns in successful episodes of market entry are consistent with what has been found using customs micro-data.

The patterns we document point toward a potentially important role for marketing and advertising activity in building market share. We show that the extensive margin of stores plays an important role in the growth of sales in a market. Since we know from the marketing literature that firms may incur direct costs in order to place their product in stores, this is suggestive of a role for marketing. In future work will make use of the Nielsen Ad Intel data to document the role played by advertising in building market share.

\section{References}

[1] Argente, D., M. Lee and S. Moreira (2018), "How Do Firms Grow? The Life Cycle of Products Matters," mimeo.

[2] Arkolakis, C. (2010), "Market Penetration Costs and the New Consumers Margin in International Trade," Journal of Politicial Economy 118 (6), 1151-1199.

[3] Bils, M. (1989), "Pricing in a Customer Market," Quarterly Journal of Economics 104 (4), 699-718.

[4] Bronnenberg, B., S. Dhar and J.-P. Dubé (2007), "Consumer Packaged Goods in the United States: National Brands, Local Branding," Journal of Marketing Research 44, 4-13.

[5] Bronnenberg, B., S. Dhar and J.-P. Dubé (2011), "Endogenous Sunk Costs and the Geographic Differences in Market Structures of CPG Categories," Quantitative Marketing and Economics 9 (1), 1-23.

[6] Drozd, L. and J. Nosal (2012), "Understanding International Prices: Customers as Capital," American Economic Review 102 (1), 364-395. 
[7] Eaton, J., S. Kortum and F. Kramarz (2011), "An Anatomy of International Trade: Evidence From French Firms," Econometrica 79 (5), 1453-1498.

[8] Eaton, J., M. Eslava, D. Jinkins, C. Krizan, and J. R. Tybout (2014), "A Search and Learning Model of Export Dynamics," mimeo.

[9] Fitzgerald, D., S. Haller and Y. Yedid-Levi (2017), "How Exporters Grow," NBER Working Paper.

[10] Foster, L., J. Haltiwanger, and C. Syverson (2008), "Reallocation, Firm Turnover, and Efficiency: Selection on Productivity or Profitability?" American Economic Review 98 (1), 394-425.

[11] Gilchrist, S., R. Schoenle, J. Sim and E. Zakrajsek (2017), "Inflation Dynamics During the Financial Crisis," American Economic Review 107 (3), 785-823.

[12] Gourio, F. and L. Rudanko (2014), "Customer Capital," Review of Economic Studies $81(3), 1102-1136$.

[13] Hall, R. (2014), "What the Cyclical Response of Advertising Reveals About Markups and Other Macroeconomic Wedges," NBER Working Paper 18370.

[14] Hottman, C., S. Redding, and D. Weinstein (2016), "Quantifying the Sources of Firm Heterogeneity," Quarterly Journal of Economics.

[15] Klemperer, P. (1995), "Competition when Consumers have Switching Costs: An Overview with Applications to Industrial Organization, Macroeconomics and International Trade," Review of Economic Studies 62 (4), 515-539.

[16] Nakamura, E. and J. Steinsson (2011), "Price Setting in Forward-Looking Customer Markets," Journal of Monetary Economics 58, 220-233.

[17] Paciello, L., A. Pozzi and N. Trachter (2017), "Price Dynamics with Customer Markets," mimeo.

[18] Ravn, M., S. Schmitt-Grohé and M. Uribe (2006), "Deep Habits," Review of Economic Studies 73 (1), 195-218.

[19] Phelps, E. and S. Winter (1970), "Optimal Price Policy under Atomistic Competition," in E. Phelps, ed., Microeconomic Foundations of Inflation and Employment Theory (New York: Norton). 
Table 1: Number of products, brands, markets, and product-brand-market triplets, 20062016

\begin{tabular}{c|c|c|c|c}
\hline Year & \# products & \# brands & \# markets & \# product-brand-markets \\
\hline 2006 & 512 & 25,266 & 205 & $1,795,611$ \\
2007 & 512 & 26,363 & 205 & $1,903,738$ \\
2008 & 512 & 26,394 & 205 & $1,911,741$ \\
2009 & 510 & 26,535 & 205 & $1,880,878$ \\
2010 & 513 & 26,824 & 205 & $1,873,141$ \\
2011 & 512 & 27,384 & 205 & $1,899,528$ \\
2012 & 520 & 27,928 & 206 & $1,931,206$ \\
2013 & 519 & 28,799 & 205 & $1,970,616$ \\
2014 & 521 & 29,230 & 205 & $2,038,847$ \\
2015 & 520 & 29,961 & 205 & $2,113,301$ \\
2016 & 520 & 28,008 & 206 & $1,995,392$ \\
\hline Avg & 516 & 27,515 & 205 & $1,937,636$
\end{tabular}

Notes: Table reports number of products (product modules), brands, markets (DMAs) and product-brandmarket triplets for each year of our sample. These are taken from the five departments we work with (Dry Grocery, Dairy, Deli, Packaged Meat, and Fresh Produce), and exclude private label brands, and cells where "counts" are the only unit of quantity. Source: Calculated based on data from The Nielsen Company (US), LLC and marketing databases provided by the Kilts Center for Marketing Data Center at The University of Chicago Booth School of Business.

Table 2: Entry and exit rates at different levels, \%, 2006-2016

\begin{tabular}{c|ll|ll|c|c}
\hline & \multicolumn{2}{|c|}{ Product } & \multicolumn{2}{c|}{ Market } & \multicolumn{2}{c}{ Product-market } \\
\hline Year & Entry & Exit & Entry & Exit & Entry & Exit \\
\hline 2006 & - & 13.0 & - & 14.2 & - & 12.3 \\
2007 & 18.5 & 13.8 & 22.3 & 15.3 & 23.0 & 13.2 \\
2008 & 14.3 & 14.7 & 15.8 & 16.1 & 15.7 & 13.9 \\
2009 & 13.8 & 13.9 & 14.4 & 16.0 & 14.0 & 13.4 \\
2010 & 14.0 & 15.0 & 15.6 & 16.2 & 14.8 & 14.0 \\
2011 & 15.1 & 15.2 & 17.8 & 16.4 & 17.2 & 14.7 \\
2012 & 17.5 & 16.4 & 18.0 & 16.6 & 17.5 & 15.0 \\
2013 & 16.3 & 15.3 & 19.0 & 16.2 & 18.6 & 14.4 \\
2014 & 19.6 & 15.0 & 19.7 & 15.6 & 19.7 & 14.3 \\
2015 & 17.3 & 16.5 & 19.8 & 16.9 & 19.2 & 15.4 \\
2016 & 11.0 & - & 11.0 & - & 10.5 & - \\
\hline Avg & 15.7 & 14.9 & 17.3 & 16.0 & 17.0 & 14.1 \\
\hline
\end{tabular}

Notes: For each product we calculate the rate of entry and exit of brands in each year, and report average of these rates across all products. For each market we calculate the rate of entry and exit of product-brands pairs in each year, and report the average of these rates across all markets. For each product-market pair we calculate the rate of entry and exit of brands in each year and report the average across all productmarkets pairs in the sample. By construction, entry is censored in 2006 and exit is censored in 2016. Source: Calculated based on data from The Nielsen Company (US), LLC and marketing databases provided by the Kilts Center for Marketing Data Center at The University of Chicago Booth School of Business. 
Table 3: Distribution of product-brand-years (\%) by change in number of markets between $t-1$ and $t$

\begin{tabular}{c|ccccccccccccccc}
\hline Change & $\leq-7$ & -6 & -5 & -4 & -3 & -2 & -1 & 0 & 1 & 2 & 3 & 4 & 5 & 6 & $\geq 7$ \\
\hline$\%$ & 6.7 & 0.8 & 1.1 & 1.4 & 2.1 & 3.5 & 8.2 & 55.8 & 6.8 & 2.8 & 1.7 & 1.2 & 0.9 & 0.7 & 6.3
\end{tabular}

Notes: For each product-brand-year we calculate the number of markets in which it has positive sales. We then record the change in the number of markets relative to the previous year. Above, we present the distribution of observations by change in the number of markets. Source: Calculated based on data from The Nielsen Company (US), LLC and marketing databases provided by the Kilts Center for Marketing Data Center at The University of Chicago Booth School of Business.

Table 4: Illustrative example of definitions

\begin{tabular}{|c|c|c|c|c|c|c|c|c|c|c|c|}
\hline Year & 2006 & 2007 & 2008 & 2009 & 2010 & 2011 & 2012 & 2013 & 2014 & 2015 & 2016 \\
\hline Market & \multicolumn{11}{|c|}{ a. Participation } \\
\hline A & $\mathrm{X}$ & $\mathrm{X}$ & $\mathrm{X}$ & & & & & $\mathrm{X}$ & $\mathrm{X}$ & $\mathrm{X}$ & $\mathrm{X}$ \\
\hline B & & $\mathrm{X}$ & $\mathrm{X}$ & $\mathrm{X}$ & $\mathrm{X}$ & & $\mathrm{X}$ & $\mathrm{X}$ & $\mathrm{X}$ & & \\
\hline $\mathrm{C}$ & $\mathrm{X}$ & $\mathrm{X}$ & & & $\mathrm{X}$ & $\mathrm{X}$ & $\mathrm{X}$ & $\mathrm{X}$ & $\mathrm{X}$ & $\mathrm{X}$ & $\mathrm{X}$ \\
\hline $\mathrm{D}$ & & $\mathrm{X}$ & $\mathrm{X}$ & & & $\mathrm{X}$ & $\mathrm{X}$ & $\mathrm{X}$ & $\mathrm{X}$ & $\mathrm{X}$ & \\
\hline $\mathrm{E}$ & $\mathrm{X}$ & $\mathrm{X}$ & $\mathrm{X}$ & $\mathrm{X}$ & $\mathrm{X}$ & $\mathrm{X}$ & $\mathrm{X}$ & $\mathrm{X}$ & $\mathrm{X}$ & $\mathrm{X}$ & $\mathrm{X}$ \\
\hline Market & \multicolumn{11}{|c|}{ b. Market tenure, topcoded at 5} \\
\hline A & cens & cens & cens & & & & & cens & cens & cens & cens \\
\hline B & & 1 & 2 & 3 & 4 & & 1 & 2 & 3 & & \\
\hline $\mathrm{C}$ & cens & cens & & & 1 & 2 & 3 & 4 & 5 & 5 & 5 \\
\hline $\mathrm{D}$ & & 1 & 2 & & & 1 & 2 & 3 & 4 & 5 & \\
\hline $\mathrm{E}$ & cens & cens & cens & cens & cens & cens & cens & cens & cens & cens & cens \\
\hline Market & \multicolumn{11}{|c|}{ c. Completed spell duration, topcoded at 5} \\
\hline $\bar{A}$ & cens & cens & cens & & & & & cens & cens & cens & cens \\
\hline B & & 4 & 4 & 4 & 4 & & 3 & 3 & 3 & & \\
\hline C & cens & cens & & & 5 & 5 & 5 & 5 & 5 & 5 & 5 \\
\hline D & & 2 & 2 & & & 5 & 5 & 5 & 5 & 5 & \\
\hline $\mathrm{E}$ & cens & cens & cens & cens & cens & cens & cens & cens & cens & cens & cens \\
\hline
\end{tabular}

Table 5: Distribution of sample value (\%) by sales spell duration and market tenure

\begin{tabular}{l|ccccc|c}
\hline & \multicolumn{7}{|c}{ Market tenure } \\
\hline Spell duration & 1 & 2 & 3 & 4 & $5+$ & cens \\
\hline 1 & 0.07 & & & & & \\
2 & 0.20 & 0.16 & & & & \\
3 & 0.12 & 0.15 & 0.05 & & & \\
4 & 0.09 & 0.13 & 0.09 & 0.04 & & \\
$5+$ & 0.69 & 1.23 & 1.40 & 1.45 & 4.18 & \\
\hline cens & 0.63 & 0.87 & 0.63 & 0.33 & & 87.50 \\
\hline
\end{tabular}

Notes: Value shares are calculated for each year in sample and then averaged across years. Source:

Calculated based on data from The Nielsen Company (US), LLC and marketing databases provided by the Kilts Center for Marketing Data Center at The University of Chicago Booth School of Business. 
Table 6: Distribution of sample observations (\%) by sales spell duration and market tenure

\begin{tabular}{l|ccccc|c}
\hline & \multicolumn{7}{|c}{ Market tenure } \\
\hline Spell duration & 1 & 2 & 3 & 4 & $5+$ & cens \\
\hline 1 & 2.65 & & & & & \\
2 & 2.80 & 2.77 & & & & \\
3 & 1.51 & 1.50 & 1.48 & & & \\
4 & 0.85 & 0.85 & 0.84 & 0.82 & & \\
$5+$ & 3.07 & 3.05 & 3.02 & 2.96 & 7.72 & \\
\hline cens & 4.13 & 3.05 & 1.68 & 0.72 & & 54.52 \\
\hline
\end{tabular}

Notes: Observation shares are calculated for each year in sample and then averaged across years. Source: Calculated based on data from The Nielsen Company (US), LLC and marketing databases provided by the Kilts Center for Marketing Data Center at The University of Chicago Booth School of Business.

Table 7: Dynamics of revenue, quantity and price

\begin{tabular}{|c|c|c|c|}
\hline Dep. var. logs & Revenue & Quantity & Price \\
\hline Spell length & \multicolumn{3}{|c|}{ Spell intercept } \\
\hline 2 years & $0.87 \quad(0.00)^{* * *}$ & $0.79 \quad(0.00)^{* * *}$ & $(0.00)^{* * *}$ \\
\hline 3 years & $1.14(0.00)^{* * *}$ & $1.04 \quad(0.00)^{* * *}$ & $(0.00)^{* * *}$ \\
\hline 4 years & $1.28(0.00)^{* * *}$ & $1.18(0.00)^{* * *}$ & $(0.00)^{* * *}$ \\
\hline $5+$ years & $1.40 \quad(0.00)^{* * *}$ & $1.31 \quad(0.00)^{* * *}$ & $(0.00) * * *$ \\
\hline Right cens. & $1.45 \quad(0.00)^{* * *}$ & $1.37 \quad(0.00)^{* * *}$ & $(0.00)^{* * *}$ \\
\hline Left cens. & $3.15 \quad(0.00)^{* * *}$ & $3.07 \quad(0.00)^{* * *}$ & $(0.00)^{* * *}$ \\
\hline Mkt. tenure & \multicolumn{3}{|c|}{ 2-year spells } \\
\hline 2 years & $(0.00) * * *$ & $-0.11(0.00)^{* * *}$ & $(0.00)^{* * *}$ \\
\hline Mkt. tenure & \multicolumn{3}{|c|}{ 3-year spells } \\
\hline 2 years & $0.52 \quad(0.00)^{* * *}$ & $0.55 \quad(0.00)^{* * *}$ & $(0.00)^{* * *}$ \\
\hline 3 years & $(0.00)^{* * *}$ & $-0.28 \quad(0.00)^{* * *}$ & $(0.00)^{* * *}$ \\
\hline Mkt. tenure & \multicolumn{3}{|c|}{ 4-year spells } \\
\hline 2 years & $0.70 \quad(0.01)^{* * *}$ & $0.72 \quad(0.01)^{* * *}$ & $(0.00)^{* * *}$ \\
\hline 3 years & $(0.01)^{* * *}$ & $0.61 \quad(0.01)^{* * *}$ & $(0.00)^{* * *}$ \\
\hline 4 years & $(0.01)^{* * *}$ & $-0.24 \quad(0.01)^{* * *}$ & $(0.00)^{* * *}$ \\
\hline Mkt. tenure & \multicolumn{3}{|c|}{$5+$ year spells } \\
\hline 2 years & $(0.00)^{* * *}$ & $0.87 \quad(0.00)^{* * *}$ & $(0.00)^{* * *}$ \\
\hline 3 years & $(0.00)^{* * *}$ & $1.01(0.00)^{* * *}$ & $(0.00)^{* * *}$ \\
\hline 4 years & $(0.00)^{* * *}$ & $1.03(0.00)^{* * *}$ & $(0.00)^{* * *}$ \\
\hline \multirow[t]{2}{*}{5 years } & $1.02 \quad(0.00)^{* * *}$ & $1.04 \quad(0.00) * * *$ & $(0.00)^{* * *}$ \\
\hline & \multicolumn{3}{|c|}{ Fixed effects } \\
\hline Prod-brand-yr & Yes & Yes & Yes \\
\hline Prod-mkt-yr & Yes & Yes & Yes \\
\hline $\mathrm{N}$ & $21,112,955$ & $21,112,955$ & $21,112,955$ \\
\hline $\mathrm{R}$ sq. & 0.77 & 0.81 & 0.85 \\
\hline
\end{tabular}

Notes: Omitted category is sales spells that last exactly one year. ${ }^{* * *}$ significant at $1 \%$. Source: Calculated based on data from The Nielsen Company (US), LLC and marketing databases provided by the Kilts Center for Marketing Data Center at The University of Chicago Booth School of Business. 
Table 8: Dynamics of number of UPCs, number of stores, revenue per store, and revenue per UPC

\begin{tabular}{|c|c|c|c|c|}
\hline Dep. var. logs & \# UPCs & Rev. per UPC & \# Stores & Rev. per store \\
\hline Spell length & \multicolumn{4}{|c|}{ Spell intercept } \\
\hline 2 years & $0.08 \quad(0.00)^{* * *}$ & $(0.00)^{* * *}$ & $0.34 \quad(0.00)^{* * *}$ & $(0.00)^{* * *}$ \\
\hline 3 years & $0.12(0.00)^{* * *}$ & $(0.00)^{* * *}$ & $0.50 \quad(0.00)^{* * *}$ & $(0.00)^{* * *}$ \\
\hline 4 years & $(0.00)^{* * *}$ & $(0.00)^{* * *}$ & $0.57 \quad(0.00)^{* * *}$ & $(0.00)^{* * *}$ \\
\hline $5+$ years & $0.13 \quad(0.00)^{* * *}$ & $(0.00) * * *$ & $0.59 \quad(0.00)^{* * *}$ & $(0.00)^{* * *}$ \\
\hline Right cens. & $0.14 \quad(0.00)^{* * *}$ & $(0.00)^{* * *}$ & $0.60 \quad(0.00)^{* * *}$ & $(0.00)^{* * *}$ \\
\hline Left cens. & $0.50 \quad(0.00)^{* * *}$ & $2.65 \quad(0.00)^{* * *}$ & $1.37 \quad(0.00)^{* * *}$ & $(0.00)^{* * *}$ \\
\hline Mkt. tenure & \multicolumn{4}{|c|}{ 2-year spells } \\
\hline 2 years & $(0.00)^{* * *}$ & $(0.00) * * *$ & $-0.07 \quad(0.00)^{* * *}$ & $(0.00)^{* * *}$ \\
\hline Mkt. tenure & \multicolumn{4}{|c|}{ 3-year spells } \\
\hline 2 years & $(0.00)^{* * *}$ & $(0.00) * * *$ & $0.15 \quad(0.00)^{* * *}$ & $(0.00)^{* * *}$ \\
\hline 3 years & $(0.00)^{* * *}$ & $(0.00) * * *$ & $-0.18 \quad(0.00)^{* * *}$ & $(0.00)^{* * *}$ \\
\hline Mkt. tenure & \multicolumn{4}{|c|}{ 4-year spells } \\
\hline 2 years & $(0.00)^{* * *}$ & $(0.00) * * *$ & $0.24 \quad(0.00) * * *$ & $(0.00)^{* * *}$ \\
\hline 3 years & $(0.00)^{* * *}$ & $(0.00)^{* * *}$ & $0.19 \quad(0.00)^{* * *}$ & $(0.00)^{* * *}$ \\
\hline 4 years & $(0.00)$ & $(0.00) * * *$ & $-0.16 \quad(0.00)^{* * *}$ & $(0.00)^{* * *}$ \\
\hline Mkt. tenure & \multicolumn{4}{|c|}{$5+$ year spells } \\
\hline 2 years & $0.13 \quad(0.00)^{* * *}$ & $(0.01)^{* * *}$ & $0.31 \quad(0.00)^{* * *}$ & $(0.00)^{* * *}$ \\
\hline 3 years & $(0.00)^{* * *}$ & $(0.01)^{* * *}$ & $(0.00)^{* * *}$ & $(0.00)^{* * *}$ \\
\hline 4 years & $(0.00)^{* * *}$ & $(0.01)^{* * *}$ & $(0.00)^{* * *}$ & $(0.00)^{* * *}$ \\
\hline 5 years & $(0.00)^{* * *}$ & $(0.00)^{* * *}$ & $0.42 \quad(0.00)^{* * *}$ & $(0.00)^{* * *}$ \\
\hline & \multicolumn{4}{|c|}{ Fixed effects } \\
\hline Prod-brand-yr & Yes & Yes & Yes & Yes \\
\hline Prod-mkt-yr & Yes & Yes & Yes & Yes \\
\hline $\mathrm{N}$ & $21,112,955$ & $21,112,955$ & $21,112,955$ & $21,112,955$ \\
\hline $\mathrm{R}$ sq. & 0.85 & 0.74 & 0.74 & 0.76 \\
\hline
\end{tabular}

Notes: Omitted category is sales spells that last exactly one year. ${ }^{* * *}$ significant at $1 \%$. Source: Calculated based on data from The Nielsen Company (US), LLC and marketing databases provided by the Kilts Center for Marketing Data Center at The University of Chicago Booth School of Business. 
Table 9: Exit Hazard

\begin{tabular}{r|cc}
\hline Market tenure & Pr. of exit rel. to 1-year mkt tenure \\
\hline 2 years & 0.01 & $(0.00)^{* * *}$ \\
3 years & -0.03 & $(0.00)^{* * *}$ \\
4 years & -0.05 & $(0.00)^{* * *}$ \\
5+ years & -0.08 & $(0.00)^{* * *}$ \\
\hline Left cens & -0.11 & $(0.00)^{* * *}$ \\
\hline & \multicolumn{2}{|c}{ Fixed Effects } \\
\hline Prod-brand-yr & Yes \\
Prod-yr-mkt & Yes \\
\hline $\mathrm{N}$ & & $19,139,873$ \\
\hline $\mathrm{R} \mathrm{sq}$. & & 0.55
\end{tabular}

Notes: Dependent variable is an indicator for exit in the next period. The omitted category is market tenure equal to one year. ${ }^{* * *}$ significant at $1 \%$. Source: Calculated based on data from The Nielsen Company (US), LLC and marketing databases provided by the Kilts Center for Marketing Data Center at The University of Chicago Booth School of Business.

Figure 1: Product level average entry and exit rates (\%)

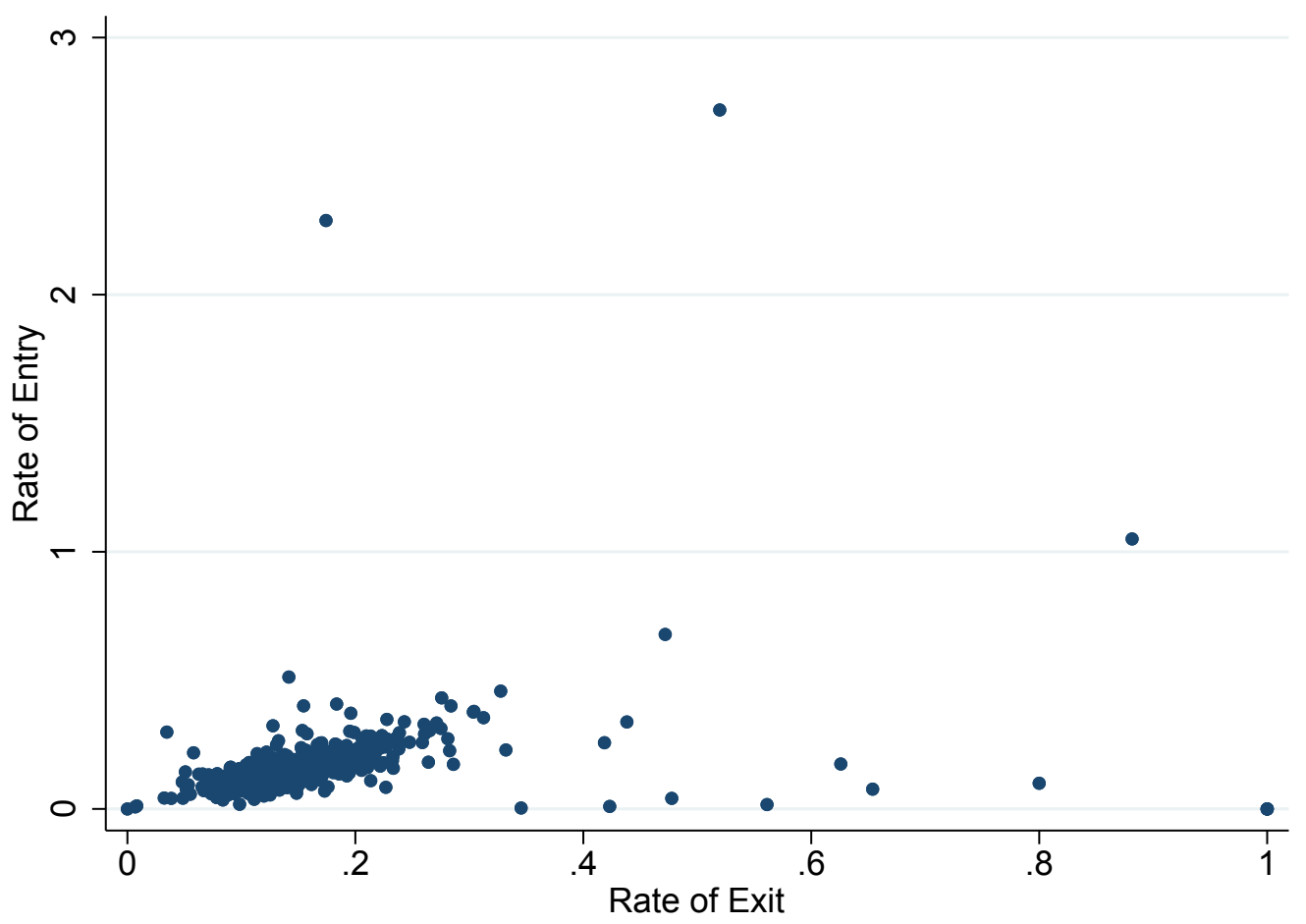

Notes: For each product we calculate the fraction of entering or exiting brands in each year. Above, we report the average over all years for each product in the sample. Source: Calculated based on data from The Nielsen Company (US), LLC and marketing databases provided by the Kilts Center for Marketing Data Center at The University of Chicago Booth School of Business. 
Figure 2: Market level average entry and exit rates (\%)

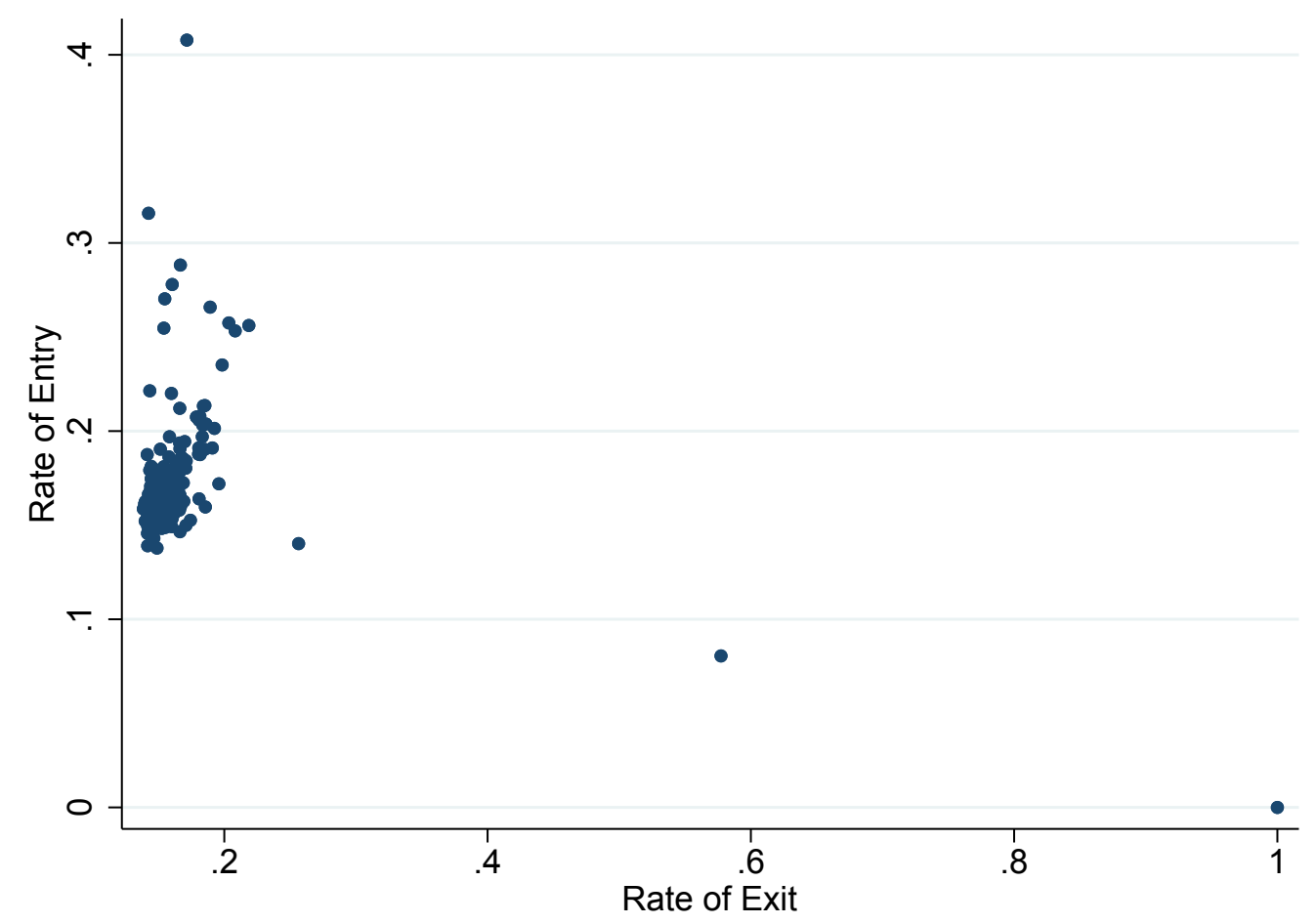

Notes: For each market we calculate the fraction of entering or exiting product-brand pairs in each year. Above, we report the average over all years for each market in the sample. Source: Calculated based on data from The Nielsen Company (US), LLC and marketing databases provided by the Kilts Center for Marketing Data Center at The University of Chicago Booth School of Business. 
Figure 3: Product-market level average entry and exit rates (\%)

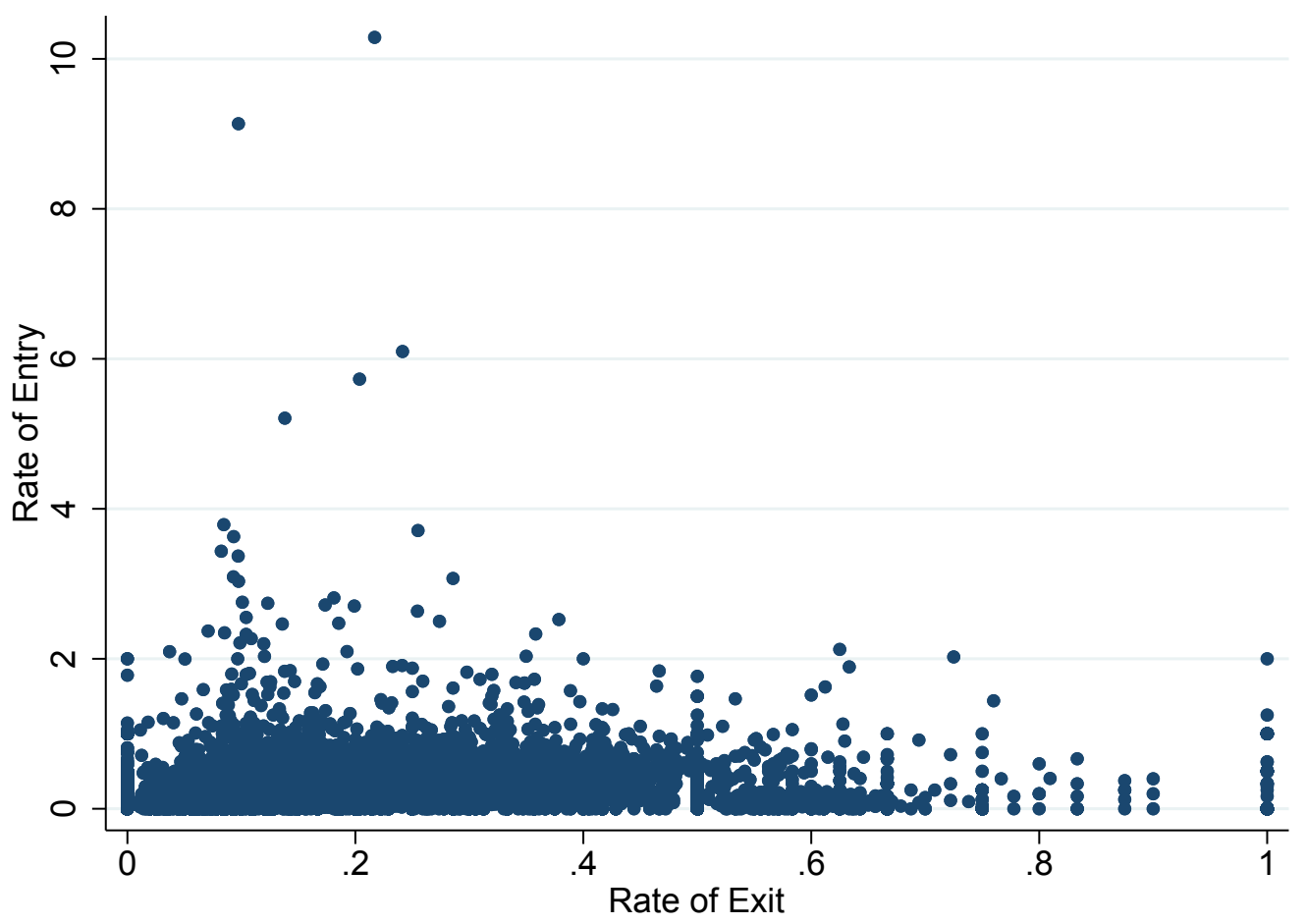

Notes: For each product-market pair we calculate the fraction of entering or exiting brands in each year. Above, we report the average over all years for each product-market in the sample. Source: Calculated based on data from The Nielsen Company (US), LLC and marketing databases provided by the Kilts Center for Marketing Data Center at The University of Chicago Booth School of Business. 
Figure 4: Brand-product-market quantity by completed spell duration and market tenure

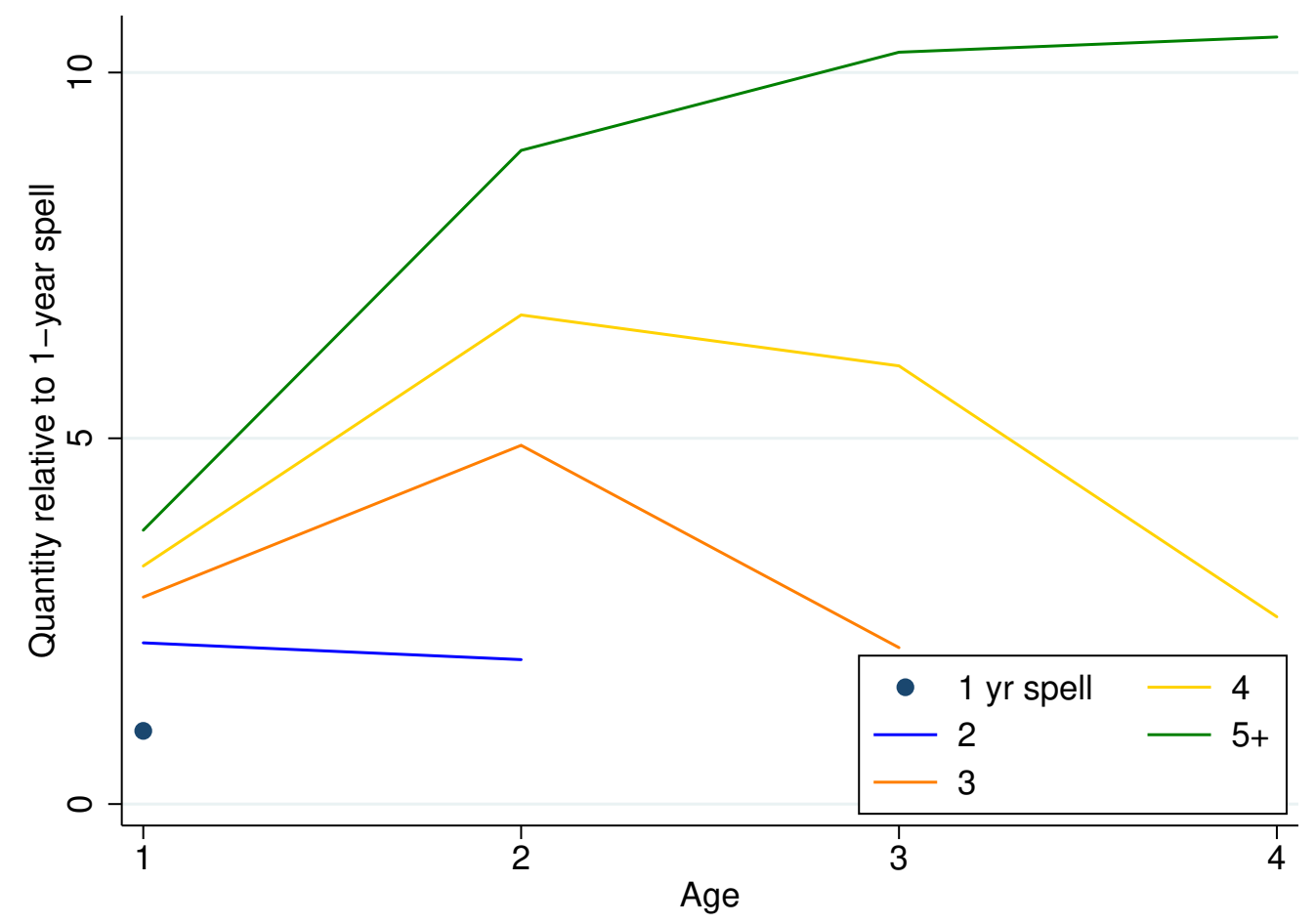

Notes: Based on exponentiating appropriate sums of coefficients from Column 2 of Table 7. Source: Calculated based on data from The Nielsen Company (US), LLC and marketing databases provided by the Kilts Center for Marketing Data Center at The University of Chicago Booth School of Business. 
Figure 5: Brand-product-market price by completed spell duration and market tenure



Notes: Based on exponentiating appropriate sums of coefficients from Column 3 of Table 7. Source: Calculated based on data from The Nielsen Company (US), LLC and marketing databases provided by the Kilts Center for Marketing Data Center at The University of Chicago Booth School of Business. 
Figure 6: Brand-product-market number of stores by completed spell duration and market tenure

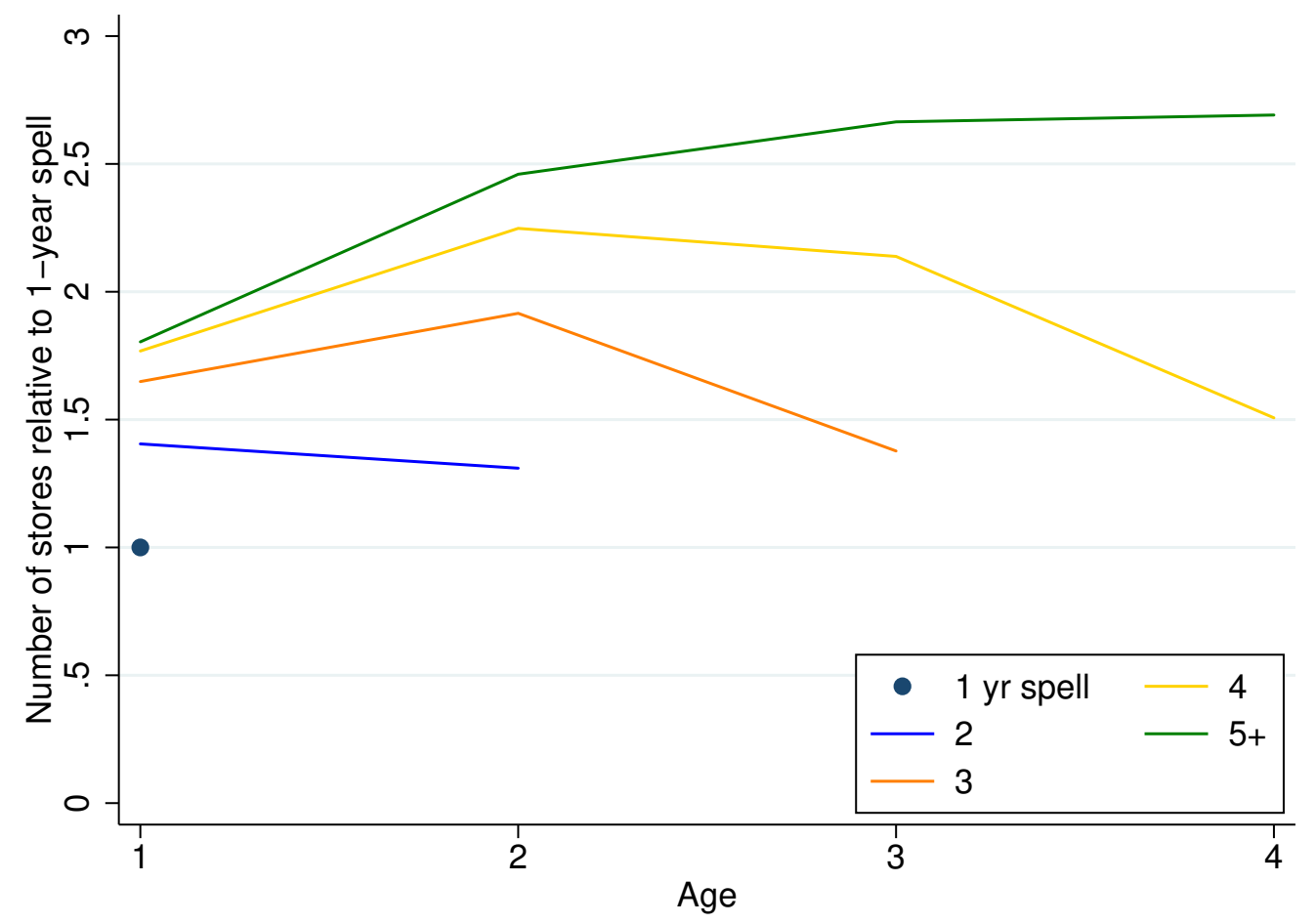

Notes: Based on exponentiating appropriate sums of coefficients from Column 3 of Table 8. Source: Calculated based on data from The Nielsen Company (US), LLC and marketing databases provided by the Kilts Center for Marketing Data Center at The University of Chicago Booth School of Business. 
Figure 7: Brand-product-market number of UPCs by completed spell duration and market tenure



Notes: Based on exponentiating appropriate sums of coefficients from Column 1 of Table 8. Source: Calculated based on data from The Nielsen Company (US), LLC and marketing databases provided by the Kilts Center for Marketing Data Center at The University of Chicago Booth School of Business. 
Figure 8: Probability of exit, by market tenure

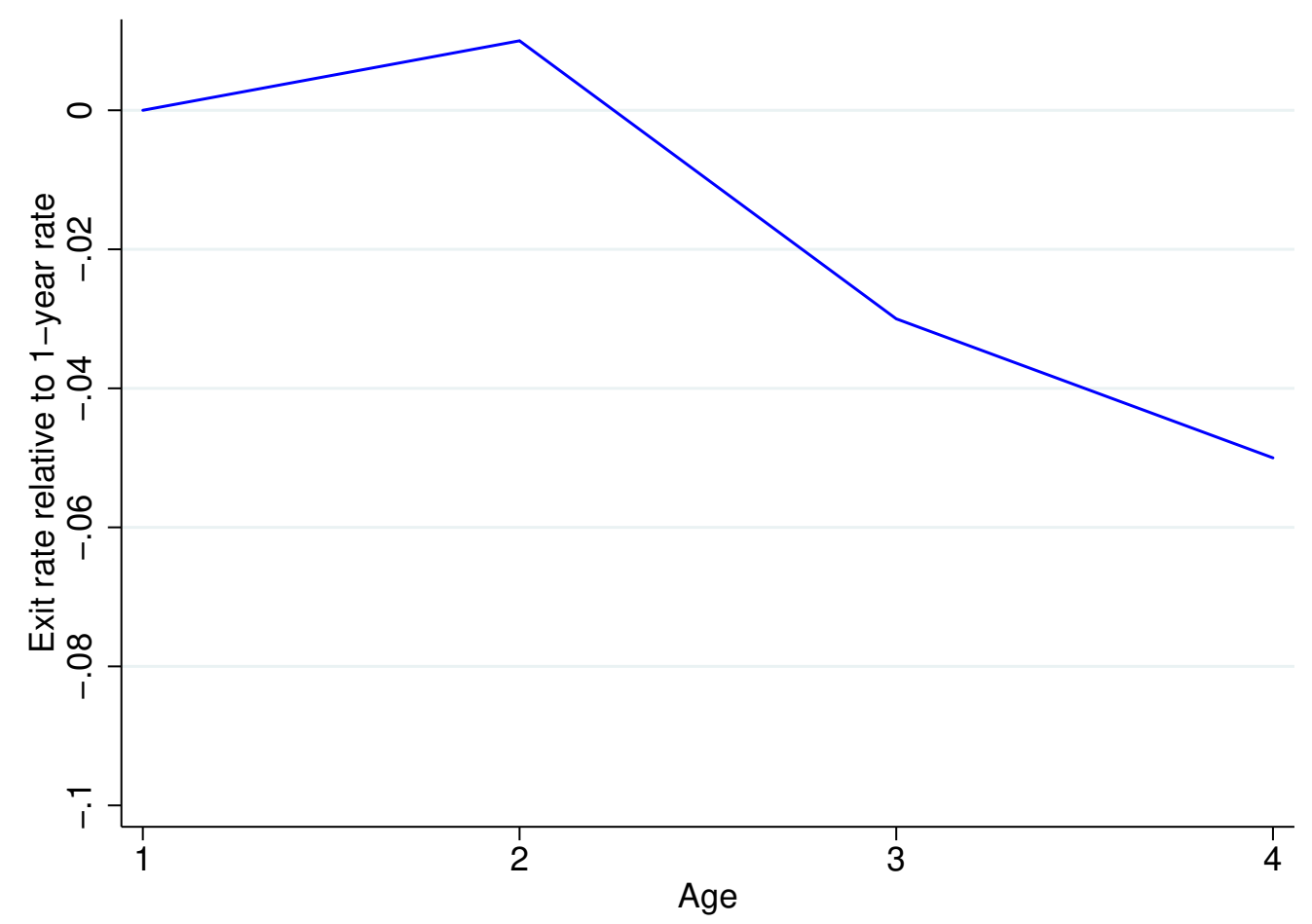

Notes: Based on coefficients from Table 9. Source: Calculated based on data from The Nielsen Company (US), LLC and marketing databases provided by the Kilts Center for Marketing Data Center at The University of Chicago Booth School of Business. 